\title{
EFFECT OF PINEAPPLE ON GOITER SIZE AND TSH LEVEL
} ABDUL REHMAN KHOKHAR ${ }^{1}$, MUHAMMAD SHAHID FARQUI ${ }^{2}$, MUHAMMAD ARSHAD QURESHI $^{3}$, TANVIR ALI KHAN SHIRWANY ${ }^{4}$, TEHSEEN IQBAL ${ }^{5}$, QURRAT UL AIN REHMAN $^{6}$

1. D.G KHAN Medical College Dera Ghazi Khan.

2. Ammer Udin M.C /P.G.M.I Lahore.

3. SAHIWAL Medical College Sahiwal.

4. Red Crescent Medical College Lahore.

5. D.G KHAN Medical College Dera Ghazi Khan.

6. P.A.E.C. Science College Dera Ghazi Khan.

\section{ABSTRACT}

BACKGROUND: Endemic goiter is a major worldwide problem and is a preventable disease. More than $12 \%$ of world population is affected. Ananas Comosus is considered to be a good source of iodine and vitamin $\mathrm{c}$, which reduce the size of goiter.

OBJECTIVE: The study objectives were, 1.To measure the goiter size reduction between study and control groups at 4,8 , and ten weeks of intervention 2.Suppression of TSH level up to $25 \%$ from base line.

MATERIALS AND METHODS: The study design was Randomized control Trial and Simple Random sampling technique was applied. The Sample Size was 7o; study group 35, control group 35. Dose Standardization was done by P.C.S.I.R laboratories complex Lahore. Exclusion Criteria. Subjects suffering from bleeding disorder, liver disease and thyrotoxicosis. History of thyroid surgery, solitary nodular goiter with history of pain and regional lymphadenopathy. Diabetes mellitis, History of use of iodized salt, contracting marriage. Goitrogenic food/marine foods intake, change in bowel habits

RESULTS: Subjects suffering from endemic goiter were selected from teaching hospital D.G Khan. Goiter size measurement and TSH estimation was done at $0,4,8$ and 10 weeks of study. Goiter size reduction from baseline $4.41 \pm 0.86 \mathrm{~cm}$ to $2.00 \pm 1.02$ after eight week of intervation was highly significant among study group $\mathrm{P}<0.000$, and TSH suppresses from baseline $2.63 \pm 0.95$ to $0.94 \pm 0.84$ after eight week $\mathrm{P}<0.000$. While changes in control group were non significant.

CONCLUSION: Ananas Comosus is good alternator remely for endemic goiter patients and a valuable goiter shrinkage agent.

KEY WORDS: PCSIR, Goiter, Ananas Comosus, TSH

\section{INTRODUCTION}

World Health Organization has declared endemic goiter a major world-wide problem and public health priority ${ }^{1}$. It is a preventable disease, and threat to social and economic development of poor countries. More than $12 \%$ of world population is affected ${ }^{2}$. Endemic goiter is more prevalent in hilly areas ${ }^{3}$. The fact that iodine deficiency plays a major role in the genesis of endemic goiter ${ }^{4}$. In Pakistan an alarming high prevalence of endemic goiter has been reported from Northern Areas of country in laps of Himalyas ${ }^{5}$.

Unreliable assessment of iodine deficiency, poor iodine supplementation, inadequate education, publicity, cost effective are deadly sins, to be avoided in order to achieve sustainable elimination of iodine deficiency ${ }^{1}$. National Utilization level of iodized salt is only $17 \%$ as projected in the Economic Survey of Pakistan. Which is drastically lower than W.H.O recommending level $>90 \%$ level due to non availability and high priece ${ }^{6}$. 
People residing in goitrous areas can only obtain enough iodine by consuming sustainable portion of their food in form of marine food, foods from iodine rich regions and using iodized salt ${ }^{7}$. Iodine is unstable and has largely been replaced by iodate due to sublimation ${ }^{8}$. Effects of iodine deficiency are worsened if selenium level is low?.

Ananas comosus has been used for its medicinal properties for hundreds of years. It has broad spectrum of actions and a good source of iodine and vitamin $\mathrm{C}^{10}$.

Bromelain is an enzyme complex, present in fruit and stem of pineapple, which is key to pineapple medicinal use $\mathrm{e}^{11}$. Bromelain is an effective antiinflammatory agent. Pineapple juice is used to treat morning sickness and sea sickness. Two slices of fresh pineapple $(25 \mathrm{mg})$ contain $1 \mathrm{mg}$ of iodine and $100 \mathrm{mg}$ of vitamin $\mathrm{C}$ is a recommended adult dose per day ${ }^{12}$. It enhances the absorption and permeability of Amoxicillin and Tetracycline in diseased tissue so its synergistic effect is documented ${ }^{13}$.

Contact dermatitis is reported as side effect of prolong use of pineapple. Safety during pregnancy and lactation is not documented yet ${ }^{14}$.

\section{MATERIALS AND METHODS}

This study was conducted in the department of physiology postgraduate medical institute, Lahore. A total member of 70 female patients with goiter were included in this study. Patients were selected from DHQ Hospital, Dera Ghazi Khan. Planned visits were made to subjects homes, along with a female nurse, to explain study design and other details to each subject. Lists of foods and fruits of high iodine content was provided to the subjects and advised not to consume these foods during study period. Subjects were randomized and divided into two groups: Study Group and Control Group. After taking a formal written consent of the subjects, each participant of study group consumed 26.7 gm per day of fresh pineapple fruit. A blood sample of $5 \mathrm{ml}$ was aseptically drawn from each subject for baseline levels of parameter to clot for 15-20 minutes. Then it was centrifuged for ten minutes at 5,000 rpm. Serum was stored. At $20 \mathrm{C}$ in serum cups. Microlab-300 Analyzer was used for serum TSH estimation by ELISA kits Human Germany. All subjects of study group had taken $27 \mathrm{gm}$ of fresh Ananas comosus daily for a period of eight weeks. Fresh pineapple weighing $26.7 \mathrm{gm}$ per day ingestion means ingesting one $\mathrm{mg}$ of iodine per day. This dose standardization was done by the PCSIR Laboratories Complex, Lahore (certificate No. FBRC/AJ/ANAL/REP/206 Dated 1-04-2010) which utilized the Pearson's composition and analysis of food 1992 method $^{15}$.

Blood samples were drawn aseptically from both study and control groups for TSH estimation at 04, 08 and ten weeks of study. Goiter size was measured with vernier

Caliper at onset of study and subsequently at four, eight and ten weeks. Findings were recorded on evaluation proforma.

\section{RESULTS}

At the start of study, no significant difference was noted in age, $\mathrm{T}_{3}, \mathrm{~T} 4$, TSH, goiter size and hemoglobin levels of both groups (Table 01).

Table 1 Baseline Characteristic on $1^{\text {st }}$ day

\begin{tabular}{|c|c|c|}
\hline Characteristics & Study group $(\mathbf{n = 2 9 )}$ & $\begin{array}{c}\text { Control group } \\
(\mathbf{n}=\mathbf{3 0})\end{array}$ \\
\hline Age in years & $19.86 \pm 3.96$ & $19.27 \pm 3.17^{*}$ \\
\hline Goiter size & $4.41 \pm 0.86 \mathrm{~cm}$ & $4.33 \pm 1.05 \mathrm{~cm}^{*}$ \\
\hline T3 & $1.29 \pm 0.46 \mathrm{ng} / \mathrm{ml}$ & $1.45 \pm 0.46 \mathrm{ng} / \mathrm{ml}^{*}$ \\
\hline T4 & $7.78 \pm 1.96 \mathrm{ug} / \mathrm{dl}$ & $6.84 \pm 2.17 \mathrm{ug} / \mathrm{dl}^{*}$ \\
\hline TSH & $2.63 \pm 0.95 \mathrm{miu} / 1$ & $2.74 \pm 1.44 \mathrm{miu} / 1$ \\
Hb\% & $11.10 \pm 2.19 \mathrm{gm} \%$ & $10.91 \pm 2.35 \mathrm{gm} \%$ \\
\hline
\end{tabular}

Results are expressed as mean $\pm \mathrm{SD}$

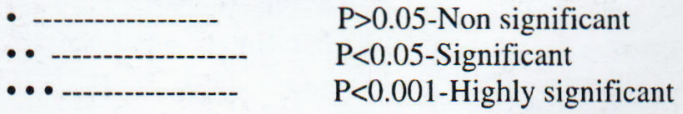

Every participant of study group consumed 26.7 gm per day of fresh pineapple fruit, while Control group did not consumed the pineapple during the study period.

After four and eight weeks of pineapple ingestion, reduction in goiter size was $31.25 \%$ and $54.83 \%$ respectively. While within control 
group, changes in goiter size at four and eight weeks were non-significant $(\mathrm{P}>0.5)$. At ten week goiter size reduction in study group was $50.03 \%$. No significant reduction was seen in control group.

TSH levels in the study group were highly significantly $(\mathrm{P}<0.001)$ reduced at four and eight weeks after pineapple ingestion. After the cassation of pineapple ingestion at eight weeks, the TSH levels returned towards the baseline and they were non-significantly different from the baseline (Table 02).

Table 02: Comparison of Goiter Size and TSH levels within control and study groups at various points of study duration

\begin{tabular}{|c|c|c|c|c|c|c|c|c|}
\hline Time & \multicolumn{2}{|c|}{ Control Group $(n=30)$} & \multicolumn{2}{|c|}{$\begin{array}{c}\text { Study Group } \\
(n=29)\end{array}$} & \multicolumn{2}{|c|}{$\begin{array}{c}\text { Control Group } \\
(n=30)\end{array}$} & \multicolumn{2}{|c|}{$\begin{array}{c}\text { Study Group } \\
(n=29)\end{array}$} \\
\hline 4 Weeks & $4.23 \pm 1.09^{*}$ & $2.38 \%$ & $2.99 \pm 0.53 * * *$ & $31.25 \%$ & $2.73 \pm 1.37$ & $0.95 \%$ & $0.41 \pm 0.19 * * *$ & $82.31 \%$ \\
\hline 8 Weeks & $4.22 \pm 1.04 *$ & $2.47 \%$ & $2.00 \pm 1.02 * * *$ & $54.83 \%$ & $2.72 \pm 1.30$ & $2.45 \%$ & $0.94 \pm 0.84 * * *$ & $56.61 \%$ \\
\hline 10 Weeks & $4.21 \pm 1.15^{*}$ & $2.98 \%$ & $2.17 \pm 1.09^{* * *}$ & $50.03 \%$ & $2.69 \pm 1.57$ & $4.36 \%$ & $2.44 \pm 0.70$ & $3.17 \%$ \\
\hline
\end{tabular}

P>0.05-Non significant

- $\quad P<0.05$-Significant

P $<0.001$-Highly significant

By applying independent sample t-test, the comparison between the two groups at four, eight and ten weeks, goiter size was highly significant $(\mathrm{P}<0.001)$ reduced in the study group as compared with the control group.
While comparing TSH levels between study and control groups, TSH levels reduced highly significantly $(\mathrm{P}<0.001)$ in the study group at four and eight weeks. At week ten the TSH levels were non significantly $(\mathrm{P}>0.05)$ different between study and the control group

(Table 03).

Table 03 Comparison of Goiter Size ad TSH levels between control and study group

\begin{tabular}{|c|c|c|c|c|}
\hline \multirow{2}{*}{ Time } & \multicolumn{2}{|c|}{ Goiter Size } & \multicolumn{2}{c|}{ TSH level } \\
\cline { 2 - 5 } & Control Group $(\mathrm{n}=30)$ & Study Group $(\mathrm{n}=29)$ & Control Group $(\mathrm{n}=30)$ & Study Group $(\mathrm{n}=29)$ \\
\hline Baseline & $4.23 \pm 1.05$ & $4.41 \pm 0.86^{*}$ & $2.74 \pm 1.44$ & $2.63 \pm 0.95^{*}$ \\
\hline 4 Weeks & $4.23 \pm 1.09^{*}$ & $2.99 \pm 0.53^{* * *}$ & $2.73 \pm 1.37$ & $0.41 \pm 0.19^{* * *}$ \\
\hline 8 Weeks & $4.22 \pm 1.04^{*}$ & $2.00 \pm 1.02^{* * *}$ & $2.72 \pm 1.30$ & $0.94 \pm 0.84^{* * *}$ \\
\hline 10 Weeks & $4.21 \pm 1.15^{*}$ & $2.17 \pm 1.09^{* * *}$ & $2.69 \pm 1.57$ & $2.44 \pm 0.70^{*}$ \\
\hline
\end{tabular}

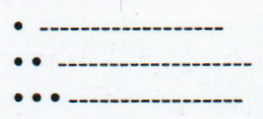

P>0.05-Non significant ${ }^{*}$

$\mathrm{P}<0.05$-Significant ${ }^{* *}$

$\mathrm{P}<0.001$-Highly significant ${ }^{* * *}$

\section{DISCUSSION}

Visible goiter causes cosmetic disfigurement of neck. Iodine deficiency leads to decreased serum $\mathrm{T}_{3}, \mathrm{~T}_{4}$, which results in high TSH level. That causes enlargement of thyroid leading to goiter ${ }^{16}$. No study was found on literature search which described the effects of fruits like pineapple on goiter size and TSH levels. This study is actually a pioneer study in this field. So, no direct comparison in possible with other studies. In our study, subjects in control and study groups were non-significantly different, as far as goiter size and thyroid status is concerned.

After the ingestion of pineapple by study group for eight weeks, goiter size and TSH levels were 
compared for each subject. At four and eight weeks,(during pineapple ingestion) goiter size was significantly reduced during pineapple ingestion in the study group and goiter size remained reduced after the cessation of pineapple ingestion at ten weeks.

As shown in Table 03, goiter size and TSH levels were non-significantly different at baseline between the control and study groups. At four and eight weeks goiter size and TSH levels were significantly reduced in the study group as compared with the control group

At ten week the goiter size in the study group remained decreased significantly in the study group as compared with the control group. The TSH levels at week ten in the study group returned towards its baseline and were non significantly different from that in the control group.

Numerous studies have been carried out, using various chemical substances to determine their effects on goiters size and TSH levels. But evidently no study appears to evaluate effects of natural substances especially fruits like pineapple and strawberries on development or otherwise of goiters.

Guglielmi et al (2004) established the role and efficiency of per-cutaneous Ethanol injection (PEI) in benign thyroid lesions. Fifty eight recurrent cystic nodules and soft autonomous functioning nodules were treated by PEI for six years $^{17}$ while in our study seventy female patients having goiter were studied. Iqbal et al (2006) concluded that significant TSH suppression was noted with thyroxin supplementation for one year which was given 50-100 ug/day among interventional group. In our study pineapple was ingested for only 8 weeks. So, duration of treatment with pineapple can be reduced significantly ${ }^{18}$.

In our study significant TSH suppression was noted in study group just after four weeks of intervention. Brenta et al (2003) described comparison of therapeutic efficacy in LThyroxin and Tri-iodo-Thyro acetic acid (TRIAC) in non toxic and nodular goiters. Thirty six women were studied for eleven months after randomization. After II months, goiter size was reduced to $42 \%$ in TRIAC group, while in our study goiter size reduction was more than $50 \%$ of initial size. In comparison with study of Brenta et al $(2003)^{19}$ pineapple ingestion produced more reduction in size within four weeks. Findings of our study also conform to recommendations of Food and Drug Administration (2013) for TSH monitoring at 6-8 weeks interval until normalization ${ }^{20}$. Our study showed significant suppression in serum TSH levels and highly significant goiter size reduction with 8 weeks of pineapple ingestion.

Zimmermann MB (2008) while tracing history various studies during last century or so, referred to a study of Marine and Kimball involving iodine intervention in school children of Akren and Ohio, USA. They treated young girls by 200 $\mathrm{mg}$ of sodium iodide for 10 days, equivalent to $1700 \mathrm{mg}$ of iodine in total, while double dose was given to older girls, while in our study 26.64 gm / day of fresh pineapple containing $1 \mathrm{mg}$ iodine was ingested by young females for eight weeks. In our study goiter size was reduced significantly with a given safe dose.

Zimmermann et al (2005) reported that iodine intake for short period in doses $500-1000 \mathrm{mg} /$ day have inhibitory effect on Thyroid function. In our study safe but effective dose of iodine (1 $\mathrm{mg}$ /day) as fresh pineapple was given for short period of eight weeks, which resulted in significant goiter size reduction and significant TSH inhibition ${ }^{22}$.

Fresh pineapple can be taken as a food item and is cost effective in quantity required. It can act as a good therapeutic agent for endemic goiter patients. It is suggested that further studies should focus to compare the relative efficacy of pineapple as source of iodine supplementation with other iodine supplementation agents.

\section{REFERENCES}

1. Sekhniashvili Z, 2008, Prevention of Iodine deficiency disorders in Georgia, Child health and environmental care studies, Summary Book- Actions WHO.1; 1-3.

2. Adwok J, Endemic goiter [on line] cited [2010 May 20, 2010]; 1-9 Accessed at WWW. Utoronto. $\mathrm{Ca} / \mathrm{OIS} / \mathrm{SIA} / \mathrm{endemic}$ goiter. 
3. Elahi S, Syed Z, Nazar L, Hassan MA, Nagara SA \& Hyder SW. 2005, A study on goiter among adolescent females referred to C.N.M, Lahore, Pak J Mad Sci.21; $1: 56-62$.

4. Gregory A, Brent P, Larsen \& DavisTF, Endemic goiter and hypothyroidism. In: Henry Mk, Melomed S, Kenmeth S.P, LarsenPR(ed). William's Endocrinology $11^{\text {Th }}$ ED. PP $391-94$.

5. Akhtar T, Zahoorullaha, Paracha PI \& Lutfullah. 2004, Impact assessment of salt iodization on prevalence of goiter in district Sawat. Pak J Med Sci. $20 ; 303-307$.

6. Economic Survey of Pakistan (2010-11) Government of Pakistan. Health and Nutrition. PP 185-87.

7. W.H.O. 2002, Environmental health criteria principles and methods for assessment of risk from essential trace elements, WHO, Geneva 1; 228.

8. Gupta MC, Mahajan BK. Food and Nutntion In: Text Book of Preventive and Social Medicine $3^{\text {rd }}$ Ed. PP 350-357.

9. Zimmermann MB. Adou P, Torresani P Zeder C, Hurrell RF. 2000, Effect of oral iodized oil on thyroid size and thyroid hormone metabolism in children with concurrent selenium and iodine deficiency Eu J cli: Nutr. 54:209-13.

10. Guangzhou, Nutritional Contents of Ananas 'Comosus' Encyclopedia for food and Nutrition in china, Food-mate group net. http:// Web foodmate. $\mathrm{Net} / \mathrm{tool} /$ yingang /06/5/002/html.

11. Maurer HR, 2001, Bromelain, Biochemistry Pharmacology and medical use, cell mol. Life sci 58; 1234-45.

12. Pineapple Health benefits [cited 2010 Aug 10] PP 1-5 accessed at. WWW. Bizaims. Com/ Coffee + break/ advices + Projects/ Pinapple health benefits.

13. Leipner J, Iten F \& Saller R, 2001, Therapy with proteolytic enzymes in rheumatic disorders. Bio Drugs: $15 ; 779-89$.

14. Kluwer W. 2005, Pineapple, Review of natural products, facts and comparison. In: Kluwer W (ed). Wolter Kluwer Health 145-67.

15. Pakistan Council of Scientific \& Industrial Research Laboratories complex, Lahore. Test Report, pearson's composition and analysis of food, 1992. PGMI Lahore No. FBRC/AJ/ANAL/ REA 206 Dated 19-04-2010.

16. Arm SM, Hex, Braveman LE. 2009, Excess iodine from an unexpected source. N Eng J Med 360: 424-6.

17. Guglielmi R, Pacella CM, Bianschini A, Bizzarri G, Rinaldi R \& Graziano FM, et al. 2004, Percutaneous ethanol injection treatment in benign thyroid lesion: Role and efficacy thy $14 ; 125-31$.

18. Iqlal A, Jorde R, Figenschau. 2006, Serum lipid levels in relation to serum TSH and effect of Thyroxine treatment on serum lipid levels in subjects with subclinical hypothyroidism. J Int. Med. 260:53-61.
19. Brenta G, Schnitman M, Fretes O, Facco E. Gurfinkel M \& Damilans, 2003, Comparative efficacy and side effects of treatment of euthyroid goiter with Levothyroxin or Triiodo thyro acetic acid. J. Cli Endocrinal Metab. 88; 5287-5292.

20. Federal Drug Association, Levothyroxine, FDA information, side effects and uses [cited 2010 September 15] PP 1-4. Accessed at h\#p:11 ccbinige/com/Levo Thyroxin in Hypothyroidism.

21. Zimmermann MB, 2008, Research on iodine deficiency and goiter in $19^{\text {th }}$ and early $20^{\text {th }}$ Centuries, J. Nutr. 138:2060-2063.

22. Zimmermann MB, Itoy, Hess SY , Fujieda K, Molinari L, 2005, High thyroid volume in children with excess dietary iodine intake. Am J. Clin Nutr. 81: 840-844.

\section{CORRESPONDENCE ADDRESS:}

Dr. Abdul Rehman Khokhar Assistant Professor of Physiology

D.G. Khan Medical College

Dera Ghazi Khan

Email: drarkhokhar@yahoo.com

Cell \# 0323-7877375 